\title{
Fat as an energy supplement for preterm infants
}

\author{
O J HANMER, W T HOULSBY, H THOM, I S ROSS, D J LLOYD, AND G RUSSELL \\ Department of Child Health and Department of Chemical Pathology, University of Aberdeen
}

SUMmARY The absorption and utilisation of dietary fat as an energy supplement was studied in 15 healthy preterm infants. They were given two formulae for periods of one week. The standard low solute feed supplied $6 \mathrm{~g}$ fat and $476 \mathrm{~kJ}(114 \mathrm{cal})$ per $\mathrm{kg}$. The high energy feed supplied $10 \mathrm{~g}$ of the same fat and $623 \mathrm{~kJ}$ (149 cal) per $\mathrm{kg}$. Fat supplementation resulted in increased absorption (significantly higher chylomicron levels) without steatorrhoea or metabolic disturbance, apparently unchanged differential absorption of fatty acids, and a significantly higher rate of weight gain (mean $25 \cdot 9 \pm 4 \cdot 6$ compared with $20 \cdot 3 \pm 4 \cdot 4 \mathrm{~g} / 24 \mathrm{~h}$ ). A high energy formula prepared with supplements of complex dietary fat is therefore of potential value in ensuring the adequate nutrition and growth of preterm infants.

The gastrointestinal energy losses of preterm infants are high ${ }^{1}$ and increase the already considerable energy requirements for growth which, if not met, may place infants at risk from malnutrition. In order to meet such energy requirements an alternative to the standard milk feed has been proposed. As large feed volumes are poorly tolerated high energy formulae have been used in attempts to improve energy balance. Although hyperosmolality is avoided by the use of fat as an energy supplement, immaturity of digestive and absorptive processes may limit the usefulness of fat in clinical practice. We have therefore studied the absorption and utilisation by preterm infants of dietary fat when the proportion in a standard feed is increased.

\section{Patients and methods}

With parental consent we studied 15 preterm infants of similar gestations and birthweights but of varying postnatal ages; clinical details are given in Table 1. All were well and already gaining weight steadily. Nearly all had regained their birthweights. None was breast fed and all had received a full strength low solute cows' milk formula supplying $2720 \mathrm{~kJ} / 1$ $(650 \mathrm{cal} / \mathrm{l})$ for at least a week.

The two milk feeds differed in fat and energy content. The standard feed, Premium*, was a low solute modified cows' milk formula containing butterfat and vegetable oils. The high energy feed was prepared by Cow and Gate at our request using an energy supplement of the same fat. No change

*Cow and Gate Ltd, Trowbridge, Wiltshire, BA14 $8 \mathrm{HZ}$. was made to the protein, lactose, mineral, or vitamin content, although the percentage of protein energy was reduced by the addition of fat. The composition of both milk feeds is shown in Table 2. A volume of $175 \mathrm{ml} / \mathrm{kg}$ a day was chosen. This supplied infants on the standard feed with $6 \mathrm{~g}$ fat and $476 \mathrm{~kJ}$ (114 cal) per $\mathrm{kg}$, and those on the high energy feed with $10 \mathrm{~g}$ fat and $623 \mathrm{~kJ}$ (149 cal) per $\mathrm{kg}$.

Infants were randomly allocated to two groups. Eight infants received the standard feed first and 7 infants the high energy feed first. All received each feed for one week. Feeds were given at 2- or 3-hourly intervals either by nasogastric tube or bottle. The

Table 1 Clinical details of 15 preterm infants

\begin{tabular}{llllll}
\hline Case & Sex & $\begin{array}{l}\text { Gestation } \\
\text { (weeks) }\end{array}$ & $\begin{array}{l}\text { Birthweight } \\
(\mathrm{g})\end{array}$ & $\begin{array}{l}\text { Age at } \\
\text { start of } \\
\text { study } \\
\text { (days) }\end{array}$ & $\begin{array}{l}\text { Weight at } \\
\text { start of } \\
\text { study }(\mathrm{g})\end{array}$ \\
\hline 1 & F & 31 & 1530 & 22 & 1710 \\
2 & M & 28 & 870 & 70 & 1700 \\
3 & F & 31 & 1540 & 13 & 1510 \\
4 & F & 31 & 1320 & 39 & 1550 \\
5 & M & 32 & 1480 & 11 & 1560 \\
6 & F & 28 & 1030 & 30 & 1350 \\
7 & M & 31 & 1550 & 16 & 1610 \\
8 & F & 30 & 1120 & 62 & 2060 \\
9 & M & 27 & 1100 & 36 & 1590 \\
10 & F & 28 & 1090 & 17 & 1180 \\
11 & F & 32 & 1680 & 11 & 1670 \\
12 & F & 29 & 1310 & 27 & 1520 \\
13 & M & 30 & 1420 & 21 & 1690 \\
14 & F & 31 & 1600 & 12 & 1640 \\
$15 *$ & M & 32 & 1050 & 15 & 1190 \\
& & & & & \\
Mean & & 30 & 1310 & 27 & 1570 \\
SD & & $1 \cdot 7$ & 250 & 18 & 220 \\
\hline
\end{tabular}


Table 2 Approximate composition of standard and high energy formulae (per 1 prepared feed)

\begin{tabular}{|c|c|c|c|c|c|c|c|c|c|}
\hline Formula & Fat $(g)$ & Protein $(g)$ & Casein $(g)$ & Whey $(g)$ & $\begin{array}{l}\text { Protein } \\
\text { energy } \%\end{array}$ & Lactose $(\mathrm{g})$ & $\begin{array}{l}\text { Minerals } \\
(g)\end{array}$ & $\begin{array}{c}\text { Energ } \\
k J(C\end{array}$ & $\begin{array}{l}\text { gy } \\
a l)\end{array}$ \\
\hline $\begin{array}{l}\text { Standard } \\
\text { High energy }\end{array}$ & $\begin{array}{l}34 \cdot 5 \\
57 \cdot 2\end{array}$ & $\begin{array}{l}18 \cdot 0 \\
18 \cdot 0\end{array}$ & $\begin{array}{l}5 \cdot 7 \\
5 \cdot 7\end{array}$ & $\begin{array}{l}12 \cdot 3 \\
12 \cdot 3\end{array}$ & $\begin{array}{r}11 \cdot 0 \\
8 \cdot 9\end{array}$ & $\begin{array}{l}69 \cdot 0 \\
69 \cdot 0\end{array}$ & $\begin{array}{l}3 \cdot 5 \\
3 \cdot 5\end{array}$ & $\begin{array}{l}2720 \\
3550\end{array}$ & $\begin{array}{l}(650) \\
(850)\end{array}$ \\
\hline
\end{tabular}

Energy $1 \mathrm{Cal} \approx 4 \cdot 18 \mathrm{~kJ}$.

high energy feed was not introduced in graduated strengths and was well tolerated. Daily weighing to the nearest $10 \mathrm{~g}$ ensured that feed volumes were increased as necessary.

After 6 days, stools were collected over a 24-hour period, during which cream was not applied to the napkin area, and urine was collected in an adhesive bag and drained intermittently. Fresh stool specimens were collected on polyethylene and frozen immediately in a sealed container. On completion each stool collection was weighed and homogenised. Aliquots were taken for analysis : water content by drying to constant weight, total lipid content by a spectrophotometric micromethod based on the sulfophosphovanillin reaction, ${ }^{2}$ fatty acids by gas chromatography, ${ }^{3}$ and sugars by thin layer chromatography. ${ }^{4}$ After each 7 -day period a prefeed sample of plasma was obtained for standard biochemical analysis, estimation of lipoproteins by nephelometry, and cholesterol by a specific enzyme method.

In view of the influence of maturity and postnatal age on gastrointestinal function each infant was used as his own control. Statistical comparisons of paired values for each infant and values for all infants on each milk feed were then made using the $t$ test.

\section{Results}

The results of stool analyses are given in Table 3. Stool collection from one infant was abandoned because of irritation by the urine bag and in 4 infants one stool collection was discarded after contamination with urine. As a result there were 10 pairs and groups of 11 and 14 infants. No significant difference in stool water or $\mathrm{pH}$ was found, but the stool lipid content while on the high energy feed was significantly higher (pairs $\mathbf{P}<0.005$, groups $\mathbf{P}<0 \cdot 01$ ).
Table 4 shows how the faecal fatty acid profile after each milk differed from the milk fatty acid profile. Medium chain fatty acids appeared to be well absorbed but with increasing chain length and saturation the proportion absorbed decreased. Faecal fatty acids profiles after the two milk feeds were not significantly different from each other.

The semi-quantitative stool sugar analysis showed glucose $(\sim 25-50 \mathrm{mg} / 100 \mathrm{ml})$, galactose $(\sim 50 / 150$ $\mathrm{mg} / 100 \mathrm{ml}$ ), and lactose (occasional trace) irrespective of feed. Chromatography of the stool fluids after hydrolysis in $1 \mathrm{~mol} / 1$ hydrochloric acid showed a 2- to 5-fold increase in glucose and galactose and the appearance of fucose.

Standard plasma biochemical analysis did not show abnormalities or significant differences between pairs and groups. The plasma calcium level of infants on the high energy feed $(2 \cdot 33 \pm 0 \cdot 13 \mathrm{mmol} / 1$; $9.32 \pm 0.52 \mathrm{mg} / 100 \mathrm{ml}$ ) was similar to that of infants on the standard feed $(2.29 \pm 0.17 \mathrm{mmol} / 1$; $9 \cdot 16 \pm 0 \cdot 68 \mathrm{mg} / 100 \mathrm{ml})$.

Table 4 Fatty acid composition of milk and stool fat from preterm infants on standard and high energy formulae (\%)

\begin{tabular}{|c|c|c|c|c|c|}
\hline \multirow[t]{3}{*}{ Principal fatty acids } & \multirow{3}{*}{$\begin{array}{l}\text { Milk } \\
\text { fat }\end{array}$} & \multicolumn{4}{|c|}{ Stool fat } \\
\hline & & \multicolumn{2}{|c|}{ Standard (1I) } & \multicolumn{2}{|c|}{ High energy (15) } \\
\hline & & Mean & $S D$ & Mean & $S D$ \\
\hline Total saturated & $47 \cdot 5$ & $61 \cdot 6$ & $6 \cdot 6$ & $58 \cdot 1$ & $7 \cdot 2$ \\
\hline $\mathrm{C}_{10}: 0$ & $2 \cdot 0$ & 一 & 一 & - & - \\
\hline $\mathrm{C}_{12}: 0$ & $8 \cdot 5$ & $2 \cdot 0$ & 0.4 & $1 \cdot 9$ & 0.6 \\
\hline $\mathrm{C}_{14}: 0$ & $7 \cdot 5$ & $5 \cdot 0$ & 0.5 & $4 \cdot 9$ & 0.9 \\
\hline $\mathrm{C}_{16}: 0$ & $18 \cdot 0$ & $29 \cdot 5$ & $3 \cdot 8$ & $27 \cdot 7$ & $4 \cdot 2$ \\
\hline $\mathrm{C}_{18}: 0$ & $7 \cdot 0$ & $25 \cdot 1$ & $3 \cdot 4$ & $23 \cdot 6$ & $3 \cdot 6$ \\
\hline Others & $4 \cdot 5$ & 二 & - & - & - \\
\hline Total unsaturated & $52 \cdot 5$ & $38 \cdot 4$ & $6 \cdot 6$ & $41 \cdot 9$ & $7 \cdot 2$ \\
\hline$C_{16}: 1$ & $3 \cdot 0$ & $1 \cdot 0$ & 0.6 & $1 \cdot 1$ & 0.5 \\
\hline $\mathrm{C}_{18}: 1$ & $33 \cdot 5$ & $28 \cdot 4$ & $2 \cdot 7$ & $31 \cdot 5$ & $5 \cdot 4$ \\
\hline $\mathrm{C}_{18}: 2$ & $14 \cdot 5$ & $9 \cdot 0$ & $4 \cdot 4$ & $9 \cdot 3$ & $2 \cdot 6$ \\
\hline $\mathrm{C}_{18: 3}$ & 0.5 & 一 & 一 & 一 & 一 \\
\hline Others & $1 \cdot 0$ & & & & \\
\hline
\end{tabular}

Table 3 Analysis of stool from preterm infants on standard and high energy formulae

\begin{tabular}{|c|c|c|c|c|c|c|c|}
\hline \multirow[t]{2}{*}{ Formula } & \multirow[t]{2}{*}{ Infants } & \multicolumn{2}{|c|}{ Fat $(\mathrm{g} / 100 \mathrm{~g})$} & \multicolumn{2}{|c|}{ Water $(\mathrm{g} / 100 \mathrm{~g})$} & \multicolumn{2}{|l|}{$p H$} \\
\hline & & Mean & $S D$ & Mean & $S D$ & Mean & $S D$ \\
\hline $\begin{array}{l}\text { Standard } \\
\text { High energy }\end{array}$ & $\begin{array}{l}11 \\
14\end{array}$ & $\begin{array}{c}7 \cdot 1 \\
12 \cdot 3^{*}\end{array}$ & $\begin{array}{l}3 \cdot 9 \\
4 \cdot 9\end{array}$ & $\begin{array}{l}75 \\
72\end{array}$ & $\begin{array}{r}11 \\
8\end{array}$ & $\begin{array}{l}6 \cdot 3 \\
6 \cdot 2\end{array}$ & $\begin{array}{l}0.6 \\
0.3\end{array}$ \\
\hline
\end{tabular}

*Grouped data: $t 2.87 \mathrm{P}<0.01$, paired data (not shown but similar): $t 3 \cdot 73 \mathrm{P}<0 \cdot 005$, from 10 infants. 
Table 5 Prefeed plasma lipoprotein profile at one week in 15 preterm infants on standard and high energy formulae

\begin{tabular}{|c|c|c|c|c|c|c|c|c|}
\hline & \multicolumn{2}{|c|}{ Chylomicrons $(\mathrm{g} / \mathrm{l})$} & \multicolumn{2}{|c|}{$\begin{array}{l}\text { Pre } \beta \text {-lipoproteins } \\
(\mathrm{g} / \mathrm{l})\end{array}$} & \multicolumn{2}{|c|}{$\beta$-lipoproteins $(\mathrm{g} / \mathrm{l})$} & \multicolumn{2}{|c|}{ Cholesterol ( $\mathrm{mimol} / \mathrm{l})$} \\
\hline & Mean & $S D$ & Mean & $S D$ & Mean & $S D$ & Mean & $S D$ \\
\hline $\begin{array}{l}\text { Standard } \\
\text { High energy }\end{array}$ & $\begin{array}{l}0.45 \\
1 \cdot 18^{*}\end{array}$ & $\begin{array}{l}0.22 \\
0.35\end{array}$ & $\begin{array}{l}1.69 \\
1 \cdot 82\end{array}$ & $\begin{array}{l}0.89 \\
1.06\end{array}$ & $\begin{array}{l}2 \cdot 32 \\
1 \cdot 92\end{array}$ & $\begin{array}{l}1.27 \\
0.56\end{array}$ & $\begin{array}{l}3 \cdot 1 \\
2 \cdot 9\end{array}$ & $\begin{array}{l}0.8 \\
0 \cdot 7\end{array}$ \\
\hline
\end{tabular}

* Grouped data: $t 6.84 \mathrm{P}<0.001$, paired data: $t 7.06 \mathrm{P}<0.001$

Conversion SI to traditional units-cholesterol: $1 \mathrm{mmol} / 1 \approx 38 \cdot 7 \mathrm{mg} / 100 \mathrm{ml}$.

The high energy feed resulted in chylomicron levels which were higher in 14 infants and lower in one. There was a significant difference between the pairs $(\mathrm{P}<0.001)$ and between the groups of infants on each milk $(P<\mathbf{0 . 0 0 1})$. Levels of pre- $\beta$-lipoprotein which reflect triglyceride clearance, cholesterol, and $\beta$-lipoprotein, did not change significantly. These results are shown in Table 5.

The high energy feed was associated with rates of weight gain which were higher in 11 infants, unchanged in one, and lower in 3 infants when comparisons with the standard feed were made (mean daily weight gain on high energy feed $25.9 \pm 4.6$; on standard feed $20.3 \mathrm{~g} \pm 4.4$ ). There were significant differences between the 15 pairs $(P<0.01)$ and between the two groups $(P<0.005)$.

\section{Discussion}

In the neonatal period the mechanisms of fat absorption are immature..$^{5-8}$ It has been estimated that at birth term infants absorb between 85 and $90 \%$ of their dietary fat, and preterm infants between only 65 and $75 \%{ }^{1}$ Energy retention increases with maturity and postnatal age 910 and by 4-6 months the proportion approaches adult values of $95 \%{ }^{11}$ Nevertheless, it is well known that increased fat intake results in greater net fat absorption in preterm infants. ${ }^{12}$

The pronounced variation in fat absorption by neonates reflects the rapidly changing functional maturity of the various processes of digestion and absorption. In this study the use of each infant as his own control has reduced the influence of physiological variation as far as possible.

The higher chylomicron levels are evidence of the increased absorption of dietary fat from the high energy formula. Despite this greater absorption the proportion of faecal fat increased. It is known that as fat intake increases less is absorbed, and a point of maximal absorption is reached; any additional increase then results in an almost identical rise in faecal fat. ${ }^{13}$ We have not calculated coefficients of absorption for the dietary fat in this study in view of the limitations which a 24-hour collection period imposes. Macroscopically, all stools appeared normal. Daily fat excretion was considerably less than $2 \mathrm{~g} / \mathrm{kg}$ so by definition steatorrhoea did not occur.

The relationship between fat excretion and calcium absorption is controversial; ${ }^{1314}$ in our study no change in dietary calcium was made and no significant effect on plasma calcium was demonstrated during the study period.

In all stools, reducing sugars were found in only small quantities and are unlikely to have interfered with fat absorption. The appearance of fucose and increased quantities of glucose and galactose after stool fluid hydrolysis probably indicates the presence of oligosaccharide material-such as fucosyllactose.

The absorption of a fatty acid is influenced by its position within the triglyceride molecule,$^{1516} \mathrm{com}$ petition from other fatty acids, ${ }^{17}$ the composition of dietary fat ${ }^{17}$ and, as we have confirmed, by chain length ${ }^{17}{ }^{18}$ and saturation. ${ }^{19}$ The mechanism by which fatty acids are absorbed remains unknown. Specific receptors have not been identified. The extracellular concentration, $\mathrm{pH}$, specificity of lipase, and adequacy of micelle formation are all important influences but the passive absorption and cellular transport of long chain fatty acids is also facilitated by an intracellular soluble fatty acid binding protein. Found predominantly in villi from the proximal and middle intestine its concentration varies in response to changes in dietary fat. ${ }^{20}$ We would expect the activity of this protein to vary with maturity and further limit the absorption of long chain fatty acids by preterm infants.

The faecal fatty acid profile is influenced not only by dietary composition and differential absorption in the small-bowel but also by bacterial hydrogenation in the large-bowel and endogenous lipid from sources such as bile and intestinal debris. By minimising these influences and avoiding qualitative change we were able to study the effect of an increase in dietary fat on differential absorption. The hydrogenation of unsaturated fatty acids by bacteria ${ }^{21}$ can be prevented by analysis within 24 hours of specimens stored at room temperature..$^{18}$ We chose to freeze stool samples during the collection period 
and did the analysis as soon as this was completed. Branched chain and odd numbered fatty acids are also produced by bacteria ${ }^{18}$ and as significant amounts were not found we can assume that the influence of bacteria was negligible. The small proportion of faecal linoleic acid suggests that endogenous biliary lipid was also of minimal influence. ${ }^{18}$ Our results therefore indicate that the differential absorption of fatty acids is unchanged by a quantitative increase in dietary fat.

A high energy formula will only be of value if it promotes increased energy retention and growth. Although the study was brief, we found that the rate of weight gain of infants on the high energy feed was significantly greater than that on the standard formula. However, the 4 infants who failed to gain weight at an increased rate all showed evidence of increased fat absorption. That this could be due to the decrease in percentage of protein energy that follows the addition of dietary fat is unlikely. The proportion of protein energy in the fat supplements feed remained higher than that in breast milk and a protein:energy ratio conducive to normal growth was preserved. ${ }^{10}$ However, the use of a high energy formula $^{10}$ or failure to ensure a neutral thermal environment can increase energy expenditure. Such variations in energy utilisation might explain why not all the 15 infants gained weight at an increased velocity on the high energy formula.

In this study the fatty acid content of the standard feed was similar to that of breast milk. We have shown that the use of a high energy feed, prepared with supplements of this fat, results in increased fat absorption and in increased nutrition and growth of preterm infants, particularly those unable to tolerate large feed volumes.

We thank the laboratory staff, Miss Allan, the staff of the Special Nursery, Aberdeen Maternity Hospital, and Cow and Gate Limited for help with this study.

\section{References}

1 Watkins J B. Mechanisms of fat absorption and the development of gastrointestinal function. Pediatr Clin North Am 1975; 22: 721-30.

2 Tomaszewski L. A new, convenient, rapid, and accurate method for determination of total lipids in feces. Clin Chim Acta 1975; 61: 113-20.

3 Matthys F, Christophe A, Verdonk G. A combined thin layer-gas chromatographic method for the analysis of fatty-acid containing stool fractions. Clin Chim Acta 1972; 36: 341-50.

4 Baron D N, Economidis J. Thin-layer chromatography for amino acids and sugars. J Clin Pathol 1963; 16: 484-6.
5 Hamosh M, Sivasubramanian K N, Salzman-Mann C, Hamosh $\mathbf{P}$. Fat digestion in the stomach of premature infants. I. Characteristics of lipase activity. J Pediatr 1978; 93: 674-9.

- Signer E, Murphy G M, Edkins S, Anderson C M. Role of bile salts in fat malabsorption of premature infants. Arch Dis Child 1974; 49: 174-80.

7 Watkins J B, Szczepanik P, Gould J B, Klein P, Lester R. Bile salt metabolism in the human premature infant. Preliminary observations of pool size and synthesis rate following prenatal administration of dexamethasone and phenobarbital. Gastroenterology 1975; 69: 706-13.

8 Norman A, Strandvik B, Ojamäe Ö. Bile acids and pancreatic enzymes during absorption in the newborn. Acta Paediatr Scand 1972; 61 : 571-6.

9 Katz L, Hamilton J R. Fat absorption in infants of birthweight less than $1300 \mathrm{gm}$.J Pediatr 1974 ; 85 : 608-14.

10 Brooke 0 G. Energy balance and metabolic rate in preterm infants fed with standard and high energy formulas. Br J Nutr 1980; 44: 13-23.

11 Fomon S J, Ziegler E E, Thomas L N, Jensen R L, Filer L J, Jr. Excretion of fat by normal full-term infants fed various milks and formulas. Am J Clin Nutr 1970; 23: 1299-313.

12 Morales S, Chung A W, Lewis J M, Messina A, Holt L E, Jr. Absorption of fat and vitamin A in premature infants. I. Effect of different levels of fat intake on the retention of fat and vitamin A. Pediatrics 1950; 6: 86-92.

13 Southgate D A T, Widdowson E M, Smits B J, Cooke WT, Walker C H M, Mathers N P. Absorption and excretion of calcium and fat by young infants. Lancet 1969; i: 487-9.

14 Shaw J C L. Evidence for defective skeletal mineralization in low birth weight infants: the absorption of calcium and fat. Pediatrics 1976; 57: 16-25.

15 Mattson F H, Volpenhein $R$ A. The digestion and absorption of triglycerides. J Biol Chem 1964; 239 : 2772-7.

16 Tomarelli R M, Meyer B J, Weaber J R, et al. Effect of positional distribution on the absorption of the fatty acids of human milk and infant formulas. $J$ Nutr 1968; 95: 583-90.

17 Fernandes J, Van de Kamer J H, Weijers H A. Differences in absorption of the various fatty acids studied in children with steatorrhea. $J$ Clin Invest 1962; 41: 488-94.

18 Gompertz S M. Sammons H G. The origin of faecal lipids. The composition of faecal fats in human subjects. Clin Chim Acta 1963; 8: 591-603.

19 Holt L E, Jr, Tidwell H C, Kirk C M, Cross D M, Neale S. Studies in fat metabolism. I. Fat absorption in normal infants. $J$ Pediatr 1935; 6: 427-80.

20 Ockner R K, Manning J A. Fatty acid-binding protein in small intestine. Identification, isolation, and evidence for its role in cellular fatty acid transport. J Clin Invest 1974; 54: 326-38.

21 Watson W C. Intestinal hydrogenation of dietary fatty acids. Clin Chim Acta 1965; 12 : 340-2.

Correspondence to Dr George Russell, Department of Child Health, University Medical Buildings, Foresterhill, Aberdeen AB9 2ZD.

Reprints will not be available.

Received 16 February 1982 